\title{
Presentation of the 2004 Kober Medal to K. Frank Austen
}

\author{
Jeffrey M. Drazen, M.D.
}

The record shows that on February 26, 1924, Karl Arnstein emigrated from Czechoslovakia via Bremen, Germany, on the ocean liner George Washington. Arnstein, an engineer, had been hired to head the newly formed Goodyear-Zeppelin organization in Akron, Ohio. What Frank's father did with his colleagues was to construct the largest manmade structure in the world, the Airdock, in which was built the 785-foot-long zeppelin USS Akron. Once in my youth, Frank was wearing his airship tie, and I referred to the embroidered aircraft as "blimps." I received a severe tongue lashing: a blimp is a shapeless airbag, while a zeppelin is an airship with a sturdy backbone. I provide this information in order for you to appreciate that Frank Austen has a heritage as a windbag, but one with a sturdy spine.

I won't attempt to summarize another man's science. That's always a big mistake, because of the risk of getting it wrong. Rather, I will give you some insight into Frank's life and some seminal events at the interface between science and personal life that led to Frank's career.

Arnstein arrived in the US at age 36 in 1924; Frank was born in 1928. As far as we can tell, he had a reasonably uneventful childhood. He headed off to a boarding school in North Carolina for the eighth grade. A note attributed to his mother reads, "It was a strict church school, which he hated, although he now says he learned a lot there. The next year, he transferred to Western Reserve Academy in Ohio. He liked that school much better, although he was still quite obstreperous, and his parents sometimes had to come to the school." This sounds like Frank!

Frank's parents persevered, and Frank persevered. He made it through the Boy Scouts as an Eagle Scout and graduated from high school. Figure 1 shows Frank at his highschool graduation with his mother, now of blessed memory. At this point, Frank was headed to Amherst College. With a glorious

This article is adapted from a presentation at the ASCI/AAP Joint Meeting, April 16-18, 2004, in Chicago, Illinois, USA.

Citation for this article: J. Clin. Invest. 114:1174-1176 (2004). doi:10.1172/JCI200423464.

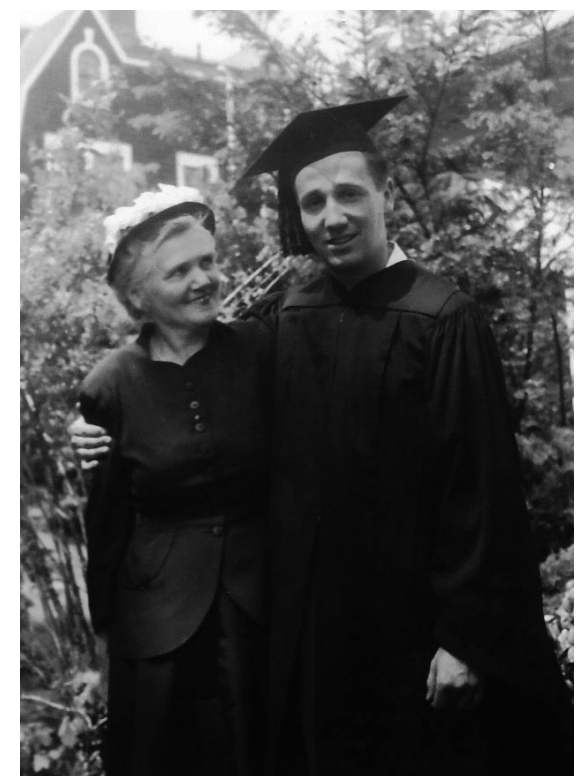

Figure 1

Frank and his mother at his high-school graduation.

summer to look forward to between high school and college, Frank went to work at a camp on Lake Erie as a lifeguard and water safety instructor before he headed to Amherst. A critical event intervened: instead of going to Amherst, Frank spent the Fall at Akron Children's Hospital with paralytic polio, paralyzed but not requiring a ventilator. His parents visited him constantly to help him through an incredibly challenging experience - spending month after month in a hospital bed, physicians not really able to help, waiting for his body to heal, with no clear idea of what was going to make the difference. He became paralyzed at the end of August, and it wasn't until December of that year that he was able to move at all.

By January, his convalescence was such that he could return home and take his freshman-year physics and chemistry at the University of Akron. By going to school in the summer, Frank was able to go on to Amherst and finish with the class with which he would have started had polio not intervened. According to Frank, it was partly the experience of being a patient for so long that then drove him to Harvard Medical
School, where he spent the next four years. During his senior year at Harvard, he took a rotation in rheumatology with Walter Bauer, then Chief of Medicine at the Massachusetts General Hospital (MGH). The two formed a fast friendship that continued for the rest of Bauer's life. Frank remains grateful to this day for their mentor-student relationship.

It was no surprise that Frank headed to the MGH to do his house staff training. Figure 2 shows Frank with his fellow house officers. He finished his internship in the summer of 1955 and was ready to head out on vacation before starting his junior residency, when polio intervened for a second time. This time, Frank was not the patient but the physician: Walter Bauer asked Frank and Jan Koch-Weser to care for the huge number of polio patients showing up in Boston hospitals. An entire floor of the White Building was devoted to these patients; Frank and Jan alternated days caring for them.

It was more than just work. Frank extracted important knowledge from this for the rest of the world. In the April 26, 1956, issue of the New England Journal of Medicine, Frank published a paper on cardiorespiratory problems observed in severe polio during the epidemic. It was classic clinical investigation. It turns out that Frank had discovered ventilation-perfusion imbalance, but he didn't know it. Frank noted that patients were dying from hypotension in these tank ventilators. When a patient was in extremis, they would haul him out of the tank and bag-mask ventilate him. The patient would pink up, look good, and then do alright. Then they'd shove him back in the tank ventilator and his oxygen saturation would drop from the mid-90s down into the low 50s. The patient would again be cyanotic, and the procedure was repeated. Although it was not known at the time, we now know four causes of hypoxemia: low PIO2, hypoventilation, right-to-left shunt, and ventilation-perfusion imbalance. Since these events were occurring at sea-level, a low PIO2 was not the cause. Frank's measurements ruled out hypoventilation, and because it was quickly reversible, it couldn't have been right-to-left shunt. So, without knowing it, 
Frank had discovered ventilation-perfusion imbalance as the cause of hypoxemia. He showed that by intubating the patient and providing positive-pressure ventilation with an oxygen mask, the hypoxemia and hypotension could be avoided. Research completed over the last 50 years has shown that the mechanism was likely atelectasis at the lung bases, common in the tank ventilator, leading to the ventilation-perfusion imbalance. Frank wrote two more papers based on his polio experience. All were published in the New England Journal of Medicine, one during Frank's junior residency and two shortly thereafter.

When Frank finished his junior residency, 11 of his 12 residency classmates headed to the National Institutes of Health (NIH). Frank hadn't heard of the NIH, so he signed up for the Berry Plan and was about to go into the Army. Walter Bauer intervened and arranged with his friend, Thomas Mattingly, who was Chief of Medicine at Walter Reed Hospital, to make Frank the head of rheumatology as soon as he finished his basic training. After completing his junior residency, Frank went off to Fort Sam Houston in Texas to do his basic training, planning to go to Walter Reed to head up rheumatology when he had completed his training.

While Frank was at Fort Sam Houston, Ike had his heart attack, and Mattingly was involved in caring for him. Frank needed his transfer orders, and Mattingly was nowhere to be found. Frank's supervisor at Fort Sam Houston looked at his CV and said, "You have three papers in the New England Journal of Medicine. You're interested in research." So he sent Frank to Walter Reed to work with Elmer Becker. After three or four months working with Becker, Frank ran into Mattingly in the hallway at Walter Reed. Mattingly said, “Austen! You're here!” Frank said, "Yes sir, I've been working with Elmer Becker." Mattingly replied, "No, I need you in rheumatology!" The next day Frank got orders to report to rheumatology. Frank went back and pleaded to be allowed to continue his research. He offered to do research and see the rheumatology consults at night. They made a deal - Frank did both jobs, getting his first opportunity to do serious bench research.

Frank finished his two years in the Army and returned to the MGH to be a senior resident. Meanwhile, Elmer Becker, who had become another of Frank's mentors and a person with whom he maintained a very close friendship, was able to get Frank a position for the following year at Mill Hill

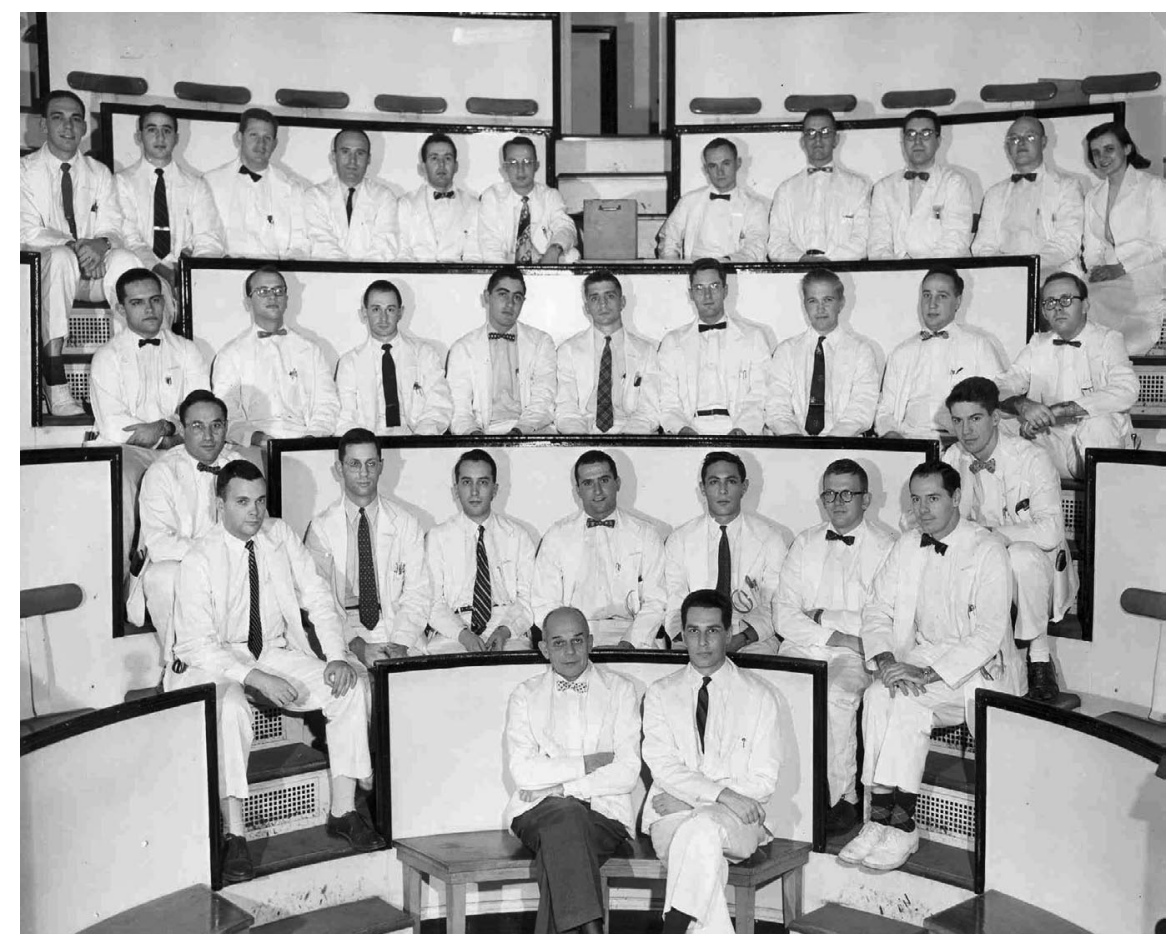

Figure 2

Frank (third row from the bottom, second seat from the right) and his fellow Massachusetts General Hospital house officers (1955).

in London, working with John Humphrey. Frank had picked Humphrey because he had read about his work in a CIBA Foundation symposium and was intrigued about exploring the biochemical basis of the acute allergic reaction. Before he headed to London, Frank made one stop on the way, to marry Joyce Chapman in April 1959 (Figure 3).

Frank did not end up working directly with John Humphrey but with Walter Brocklehurst, who had just completed his doctoral thesis in which he showed that a substance released from guinea-pig lungs

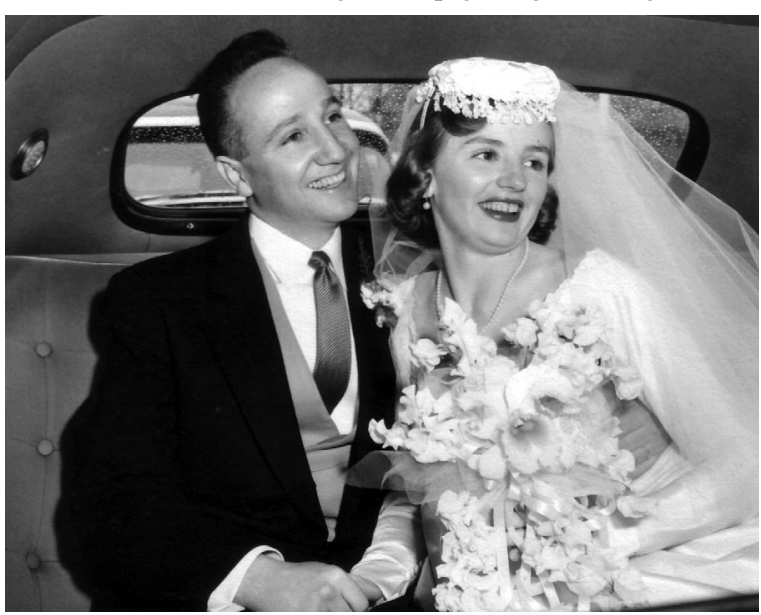

Figure 3

Frank and his bride, Joyce Chapman Austen. during anaphylaxis caused constriction of human as well as guinea pig bronchioles. The constriction was rapidly reversed by the addition of adrenaline. Identifying the nature of this material and how its release was regulated occupied the next 20 years of Frank's life. From this work with Brocklehurst, he published a number of papers, including one in Nature in 1960, which examined regulation of the release of histamine as well as slow-reacting substance from chopped guinea-pig lung. This was the beginning of Frank's

passionate research agenda - to understand the biochemistry of acute allergic reactions. He has studied the molecules involved in this reaction, how they are regulated, what they do, what cells produce them, and how they can be modulated. About ten years ago, I had lunch with Brocklehurst. He told me that at the end of their two-year association, he wasn't sure who was the postdoctoral fellow and who was the mentor. He said Frank was running him ragged. 


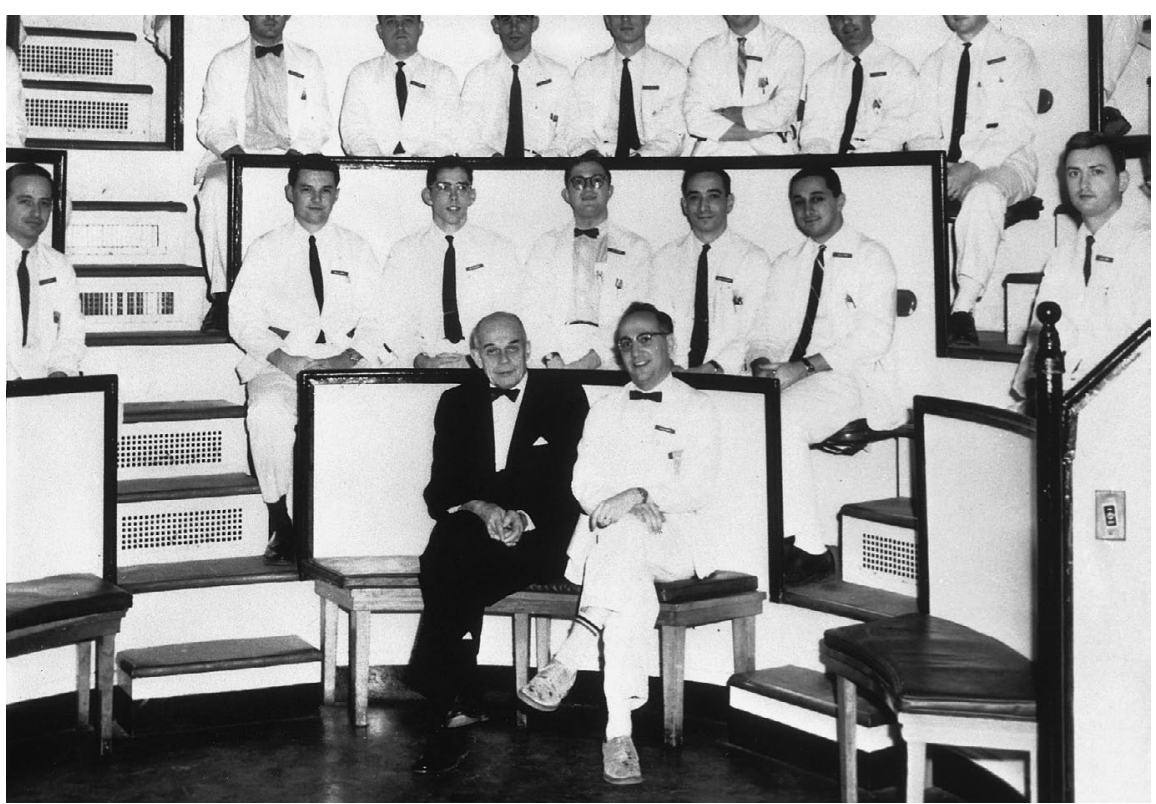

Figure 4

Frank, the chief resident, in the seat of honor beside Walter Bauer.

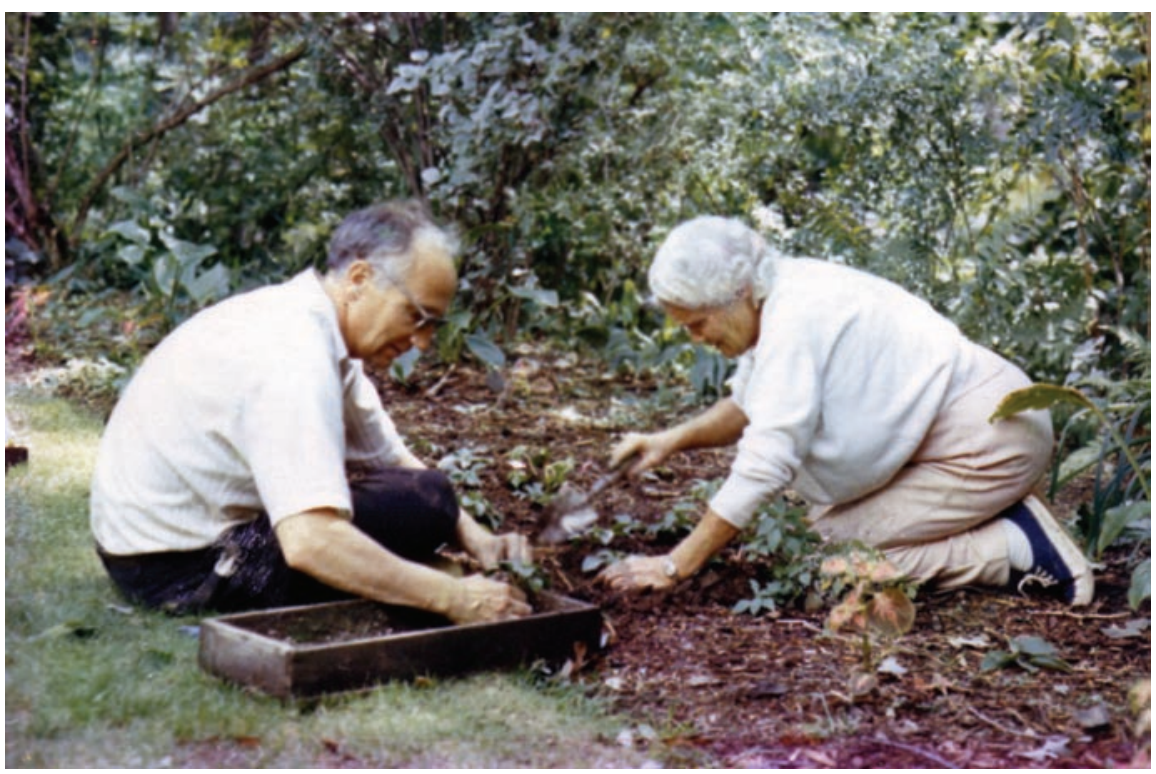

Figure 5

Frank and his mother working in the garden.

Frank returned to the MGH to be chief resident. Figure 4 shows him sitting next to Bauer, the honored seat for the chief resident back in those times. He completed his chief residency and headed to Johns Hopkins, where he would study with Manfred Mayer because he needed to learn immunochemistry if he were really going to be an immunologist. However, after only six months, events in Boston required Frank to return to the $\mathrm{MGH}$, where he set up a laboratory in infectious disease. In 1964, when Bob Ebert took over as Chief of Medi- cine, Frank was appointed head of pulmonary and from 1964 to 1966 maintained his lab at the MGH. Then, in 1966, Ebert became Dean of Harvard Medical School, and Frank moved from the MGH to the Robert B. Brigham Hospital.

Now, for those of you who are not familiar with the Harvard system, you would think that this wasn't much of a move. But I can tell you that Frank's moving from the MGH to the Robert B. Brigham was probably as big a culture shift for Frank as moving from Europe to the US at age
36 was for his father. Frank set off on his own to build his fortune with a laboratory that could investigate the scientific basis of disease. He took Peter Shur and John David with him. This hospital is where I first met him in 1972 .

Frank stuck to his theme of understanding the biochemistry of the acute allergic response. The mast cell occupied a lot of his thoughts. Frank has published 527 peer-reviewed publications since 1955 , and two-thirds are about mast cells. This has been his contribution - teaching us about this cell type and how it functions. Interestingly, seven of his last ten publications, including one published in 2004, dealt with mast cells. Frank has had nearly 50 years of continuous NIH support. He has never had a grant turned back. An enviable record!

Frank has trained many people. There are hundreds in academic positions, and over 90 former fellows are full professors or an equivalent rank at the NIH or other research institutes. Frank spawned a generation of academic research scientists, many of whom are members of this society.

In addition to the scientific family, Frank is a devoted family man. Figure 5 shows him with his late mother, working in the garden. Today he has his own dirt pile at home, where he spends a lot of time. When he is not digging in the dirt, he is usually doing some community activity, such as coaching his state champion soccer team. I think Frank was attracted to the mast cell because it looks somewhat like a soccer ball.

Frank has had a rich personal life as well as a life devoted to the science of the acute allergic response. He has taught us about the biology of the mast cell and the acute allergic response and the many mediators that produce the setting for common diseases, such as asthma, and uncommon diseases, such as mastocytosis. He has trained literally hundreds of investigators who have gone on to train hundreds of investigators each. He has done this by asking important questions and requiring his fellows, his trainees, and his visiting scientists to answer them as crisply as possible.

\section{Acknowledgment}

The author wishes to thank Caryn Sandrew for her assistance in the preparation of this manuscript.

Address correspondence to: Jeffrey M. Drazen, M.D., New England Journal of Medicine, 10 Shattuck St., Boston, Massachusetts 02115. E-mail: jdrazen@nejm.org. 